\title{
Developing a generic biosecurity risk assessment model for imports
}

\author{
L.E. Jamieson ${ }^{1,4}$, O. Woodberry ${ }^{2}$, C.M. McDonald ${ }^{3}$ and M. Ormsby ${ }^{3}$ \\ ${ }^{1}$ The New Zealand Institute for Plant \& Food Research Limited, \\ $120 \mathrm{Mt}$ Albert Rd, Mt Albert, Auckland, New Zealand \\ ${ }^{2}$ Bayesian Intelligence, 2/21 The Parade, Clarinda 3168, Victoria, Australia \\ ${ }^{3}$ Ministry for Primary Industries, P.O. Box 2526, Wellington, New Zealand \\ ${ }^{4}$ Better Border Biosecurity (B3), New Zealand (b3nz.org) \\ Corresponding author: Lisa.Jamieson@plantandfood.co.nz
}

\begin{abstract}
Developing decision support models to evaluate biosecurity risks objectively helps decision makers manage the associated risks with importation of goods. We report on the development of a prototype generic risk assessment model to determine the probability and consequences of a plant pest establishment and spread event for an infection point, given the biosecurity risk organism arrives via various pathways. The model has a number of sub-models, including: entry pathway, which models the ratio of infested units coming from any pathway supplying the infection point; establishment and spread, which models the chance of an establishment and spread event occuring at an infection point; and consequences, which models the consequences of any establishment or spread event occurring at the site. Future research is planned to develop a generic input interface to generate a support tool to allow a user to investigate the impacts of alternative 'what-if' scenarios and to test the model on real-world plant pest inputs.
\end{abstract}

Keywords biosecurity, risk assessment, Bayesian network, plant import pathways.

\section{INTRODUCTION}

Biosecurity professionals and regulators routinely judge risk on import pathways based on scientific information, probabilities and expert opinion, and often where data are scarce and there is a high level of uncertainty (Wintle \& Nicholson 2014). Experts consider many interacting variables on a pathway including: seasonality, risk organism density at the beginning of the pathway, risk mitigation treatments on the pathway, natural mortality of the risk organism on the pathway, volume of trade, founder population size that enables a risk organism to establish, host availability, dispersal ability and establishment rate, commodity distribution patterns, consequences (economic, environmental, human health, social/cultural), and the cost and likelihood of success for various potential eradication options. Understanding the risks on import pathways becomes increasingly complex when pests have multiple entry pathways.

Bayesian networks (BNs) are graphical modelling tools that are generally recommended for exploring 'what-if' scenarios, visualizing systems and problems and for communication between stakeholders during decision making (Wintle \& Nicholson 2014). BNs are causal probabilistic 
graphs, which represent a set of random variables and the conditional dependencies between them. They can be used to compute probabilities via either predictive or diagnostic inference, or a mixture of both. BNs are particularly useful for reasoning about complex systems with uncertainty, and are also effective for modeling systems where data are incomplete or uncertain.

The Ministry for Primary Industries (MPI) aims to develop models/tools to help evaluate the factors influencing biosecurity risks; to establish an understanding of base line risk levels; to develop methods of assessing the efficacy of treatments; and to examine all of these under different scenarios. Of interest to biosecurity would be scenario testing within a generic model/tool: 1) What happens when import volumes of host material increase (from infested areas)? 2) What happens if infestation levels increase due to factors such as climate change, pest outbreaks, changes in pest control, such as a loss of the use of an insecticide? 3) Which pathway (where there are multiple) would achieve the greatest overall reduction in the incidence of risk organism arriving, surviving and establishing from the least amount of input into risk reduction measures, and what are the relative risks when comparing pathways? 4) When/where is the most cost-effective point for intervention (risk reduction) on a pathway or multiple pathways? 5) What happens when the distribution of host material into an area changes (e.g. due to an event such as a large multi-day concert)? 6) What happens to the potential establishment rate of a pest organism when the level of intervention is reduced at a particular point on the pathway? 7) Given the source pest density, what is the likelihood of a location being exposed to pests when the volume of units arriving on a pathway increases? 8) What are the economic consequences of a pest establishing at all potential locations, compared to only a subset of these? 9) Given the exposure of a location to pests, what level of efficacy is required in pre-border/post-border treatment to reduce the exposure to pests by $50 \%$ ?

One of the aims of the Better Border Biosecurity (B3) programme is to develop decision support models to evaluate biosecurity risks objectively which help decision makers manage the associated risks with importation of goods. This paper describes the development of a prototype generic risk assessment model to enable biosecurity managers such as MPI to explore the probability and consequences of a biosecurity risk establishment and spread event for an infection point, given a biosecurity risk organism arrives from various pathways.

\section{MATERIALS AND METHODS}

The initial stage of the project involved the development of a conceptual diagram to describe the variables that may influence the level of biosecurity risk on a generic import pathway of any risk organism that might be detrimental to plant production in New Zealand, including the likelihood of entry, exposure and establishment and consequences (Figure 1).

In a review of methods for assessing and managing market access and biosecurity risks using systems approaches, Bayesian Networks (BNs) were identified as a valuable tool to assess and manage risks using different scenarios (Jamieson et al. 2013). In that review, the following steps were identified as important for developing a generic tool to support biosecurity risk assessment for import pathways: 1) using expert knowledge of the system to set up the conceptual model and a graphical display of variables and inter-relationships; 2 ) analysing the whole complex risk assessment system as smaller sub-models; 3 ) determining the quantity of usable data/ expert opinion available for each variable/node; 4) incorporating available information, empirical observations and expert models in a coherent probabilistic and logical way that can be readily updated and validated (this is where using cause-and-effect models such as BNs is advantageous); and 5) evaluating uncertainty and validation procedures. As a result of the review by Jamieson et al. (2013), BNs were selected as appropriate for modeling import pathway(s).

An initial BN model was built by Owen Woodberry (Bayesian Intelligence) using the GeNIe Bayesian network tool (https://dslpitt.org/ genie/) and modifications were made based on 


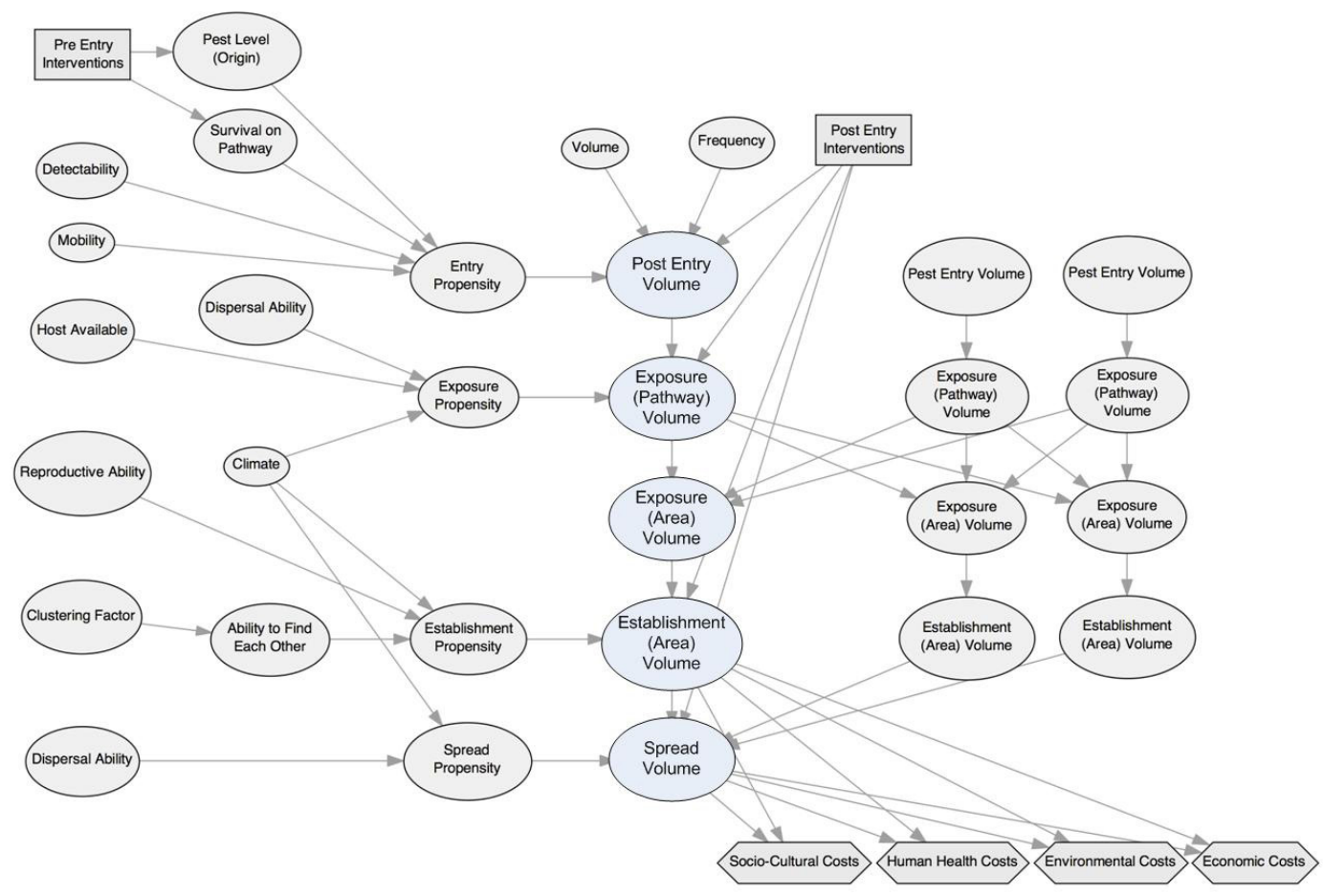

Figure 1 Conceptual diagram of the variables (or nodes) influencing biosecurity risks on import pathways. Rectangle nodes are the interventions (pre-border, at border and/or post border). Shaded oval nodes are the main pathway nodes $(\mathrm{Vol}=$ volume, $\mathrm{Amt}=$ amount $)$. Rhomboid nodes are the impacts.

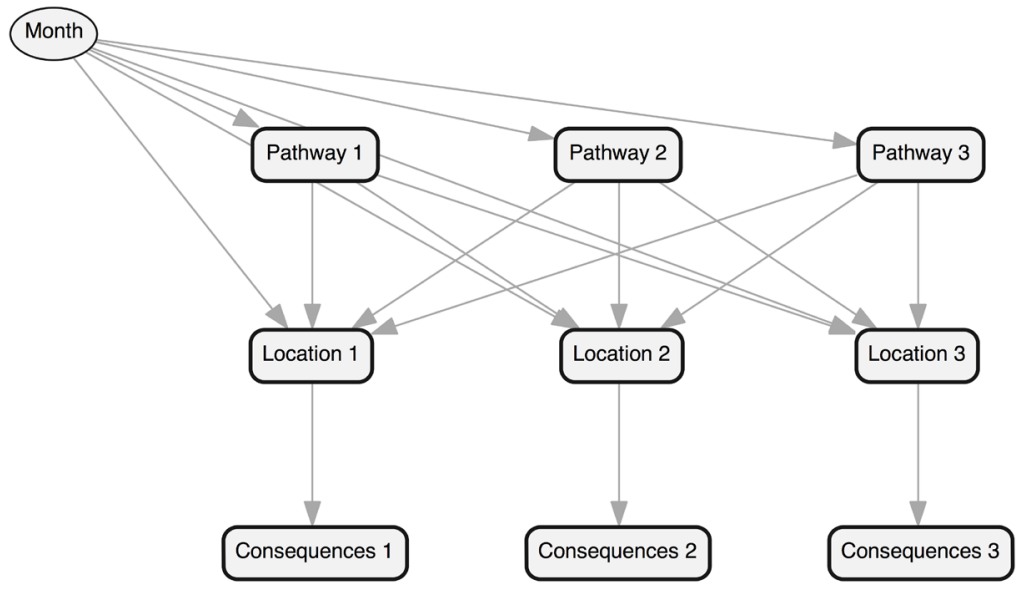

Figure 2 Main upper level model architecture for the generic biosecurity risk assessment model for imports with component nodes/sub-models. 
feedback from the other authors. A model support tool was then developed, and implemented in java, utilising the GeNIe Application Programming Interface (API), allowing the user to specify the inputs in to the model, i.e., spatial resolutions and input distributions, using excel spread sheets. During an iterative development process, further refinements of the underlying models and tools were developed (including addition of sub-models) by Owen Woodberry and then evaluated and improved, based on feedback received from the other authors. The model is at a point where it is ready for testing and validation using case studies which will be published later.

\section{RESULTS}

The model was designed to run in combination with a GIS (Geographical Information System) tool with two passes. The first pass runs the 'Pathway' sub-models for all pest entry ports, determining the expected percentage of infected units arriving from the pathway to any infection point it supplies. The second pass runs the 'Location' and 'Consequences' sub-models for all infection points, taking output on pest densities from the first pass using the entry pathways as the input.

The temporal scale of the model is pest specific. That is, there would be a 'window' where pests, coming from multiple pathways, would potentially intermingle at an infection point, taking into consideration the life span of individual pests. At this stage, models are run on a monthly basis, with inputs given for all months spanning an entire year.

\section{Model architecture}

The high-level, model architecture of a prototype generic risk assessment model that determines the likelihood and consequences of an establishment and/or spread event of a pest type at an infection point is shown in Figure 2. The model has a number of sub-models, each discussed in detail below: Pathways (Figure 3), which model the infected units coming from any pathway feeding the locations; Exposure Pests (not shown in Figure 2, see Annex Figure 4), which model the number of pests entering and transferring from the commodity or pathway to a suitable host or environment (exposure of pest to location); Locations (Annex Figure 5), which models the pests arriving at a location; and Consequences (Annex Figure 6), which model expected costs of establishment and spread at the location. The Month variable is used as a switch; to select the monthly specific input values, such as number of units arriving and likely establishment rates. A description of the variables (or nodes) of the high level generic biosecurity risk assessment model is shown in Table 1.

\section{Pathway sub-model}

The Pathway sub-model/node (Figure 3) determines the density of infected units arriving from any source/commodity pathway. A description of the variables (or nodes) of the Pathway sub-model is shown in Annex Table 2. The pest density is tracked through a number of stages: source, pre-border, at-border, and/or post-border. Between stages, the pest density is affected by the various treatment interventions implemented and natural mortality. The nodes without parent nodes have their initial parameterization values entered via an input spreadsheet. These values might be specific numbers or distributions. The Source Pest Density node is specified as a function across months to reflect favourable (or unfavourable) climate (or other e.g. cropping cycles) conditions at the source.

\section{Exposure pests sub-model}

The Exposure Pests sub-model (Annex Figure 4) determines the number of pests entering (and being transferred or exposed to) a location from a pathway. A description of the variables (or nodes) of the Exposure sub-model is shown in Annex Table 3. The number of pests entering a location is a function of the pest density (input from the Pathway sub-model), the number of units coming to the location (distribution proportional to the total units) and the pests per unit. Each pest has a chance of being exposed to the environment, which implicitly captures considerations of pest specific 
Table 1 Main upper level generic biosecurity risk assessment model for imports. Description of the variables and their relationship to one another.

\begin{tabular}{|c|c|c|c|c|}
\hline Node/Sub-model ${ }^{1}$ & Description & Units & $\begin{array}{l}\text { Parent } \\
\text { nodes }\end{array}$ & Relationship \\
\hline Month & $\begin{array}{l}\text { Month of the current model } \\
\text { run. Value is entered as } \\
\text { an integer representing the } \\
\text { month. }\end{array}$ & $\begin{array}{l}\text { Enumerated } \\
\text { Month } \\
\text { (e.g., Jan=1, } \\
\text { Feb }=2, \ldots)\end{array}$ & NA & NA \\
\hline Pathway $1,2, \ldots$ & $\begin{array}{l}\text { Determines the ratio of units } \\
\text { infected coming from an entry } \\
\text { pathway. }\end{array}$ & NA & Month & $\begin{array}{l}\text { Switches month } \\
\text { specific inputs. }\end{array}$ \\
\hline \multirow[t]{2}{*}{ Location $1,2, \ldots$} & \multirow[t]{2}{*}{$\begin{array}{l}\text { Determines the chance of an } \\
\text { establishment and/or spread } \\
\text { event for an infection point. }\end{array}$} & \multirow[t]{2}{*}{ NA } & $\begin{array}{l}\text { Pathway } \\
1,2, \ldots\end{array}$ & $\begin{array}{l}\text { For each potential } \\
\text { infection pathway, } \\
\text { ratio of units } \\
\text { infested taken as } \\
\text { input. }\end{array}$ \\
\hline & & & Month & $\begin{array}{l}\text { Month switches } \\
\text { between month } \\
\text { specific inputs. }\end{array}$ \\
\hline $\begin{array}{l}\text { Location } 1,2, \ldots \\
\text { Consequences }\end{array}$ & $\begin{array}{l}\text { Determines the consequences } \\
\text { of establishment and spread } \\
\text { events at the location. }\end{array}$ & NA & $\begin{array}{l}\text { Location } \\
1,2, \ldots\end{array}$ & $\begin{array}{l}\text { For each location, } \\
\text { takes the chances } \\
\text { of establishment } \\
\text { and spread. }\end{array}$ \\
\hline
\end{tabular}

${ }^{1}$ See text for description of nodes/sub-models

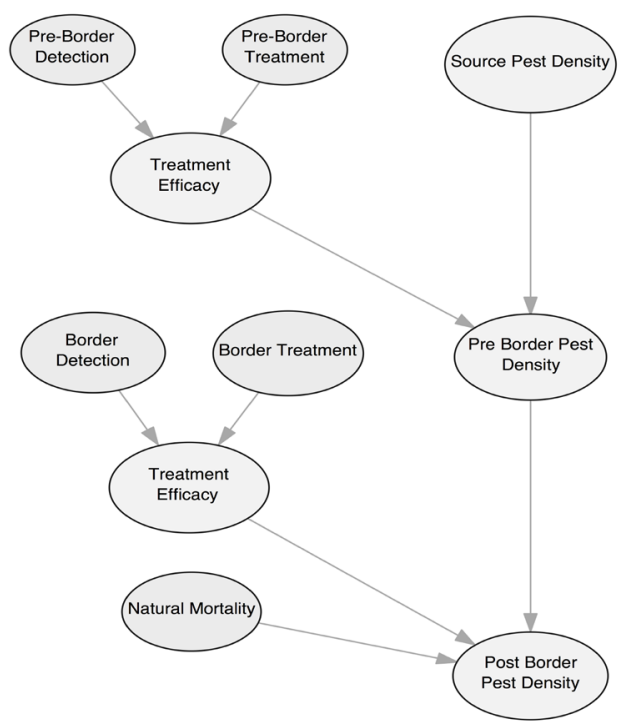

Figure 3 The Pathway sub-model for the generic biosecurity risk assessment model for imports with component nodes/sub-models. 
host availability, climate and dispersal ability.

\section{Location sub-model}

The Location sub-model (Annex Figure 5) determines the chance of an establishment and spread event occurring for any infection point. A description of the variables (or nodes) of the Location sub-model is shown in Annex Table 4. The total number of pests exposed at a location (Exposure Pests node) is the aggregate of the number of pests reaching the location from each pathway. Each pest has a chance of establishing, which is a function of founder population size, host availability and climate conditions. This is presumed to be a fixed rate per pest for each month. The chance of a spread event depends on the establishment occurring and not being eradicated (based on detection and control effectiveness). If this is the case, a spread event will occur with some likelihood. The nodes without parents have their initial parameterization input via an input spreadsheet. These values might be specific numbers or distributions. The Establishment Rate node is specified as a function across months, capturing climatic considerations.

\section{Consequences sub-model}

The Consequences sub-model (Annex Figure 6) estimates the economic, environmental, human health and social/cultural costs (or impacts) associated with an establishment and/or spread event occurring at an infection point. The Annex Table 5 shows the variables in the Exposure sub-model. The costs occur in four different categories enabling them to be considered independently together with the costs for the treatment/eradication interventions (not modelled explicitly). The costs may have different units (e.g., dollars, number of threatened species, and human health as the number of lives affected, i.e. made ill, incapacitated, lost). Currently, these values use the same utility units, but they are not directly comparable. This should be improved in subsequent models. The Consequences sub-model takes as an input the chance of establishment and spread events from the Location sub-model. Each cost (or impact) category has separate costs for an establishment and a spread event and the net cost is calculated as an expected cost (probability x cost).

This sub-model could be created using utility nodes. However, the GeNIe BN tool (which was used to implement the $\mathrm{BN}$ ) disallows mixing of equation nodes (used for the rest of the network) and other node types.

\section{Model Support Tool}

A Model Support Tool was created and implemented in Java, utilising the GeNIe API. The Model Support Tool is driven by a control spreadsheet, specifying the pathways (source/commodity), the locations within New Zealand to be included and the input values - i.e. distributions for the parentless nodes in the sub-model templates. The tool, firstly, creates a high-level Bayesian Network (BN), which is built from the sub-models. This $\mathrm{BN}$ is saved and then used to determine baseline values and expected costs for each month.

All variables in the $\mathrm{BN}$ use the GeNIe equation nodes, which do not require continuous variables to be discretised and have their conditional probability function defined by a mathematical expression. This was justified because the majority of variables are continuous and the relationships between them can be easily represented using equations. This also allows the GeNIe sampling inference functionality to be utilised. The GeNIe tool does not allow equation nodes to be mixed with other nodes (although, in principle, this is possible). Consequently, non-continuous variables (i.e., discrete and Boolean) are enumerated. Also, cost (i.e., utility) variables would normally be handled by utility nodes, allowing for easier interpretation of the results. However, these can be handled equivalently as continuous variables, which is further justified by the separation of consequences into different scales that do not necessarily correspond to each other.

The main GeNIe sampling inference engine has limited support for entering evidence into non-root nodes (i.e. nodes with parents). 
Consequently, alternative support tools were reviewed to perform such inference. It was decided to create a purpose-built inference tool that provides this support, utilising much of the GeNIe functionality. The tool performs a basic logic sampling, taking interval evidence for any node in the network. The performance of the tool is only slightly inferior to the inbuilt inference algorithm, dependent on the specificity of the evidence (i.e. tighter evidence intervals will take longer). Further testing will be required to determine if the performance is adequate, but the prototype tool demonstrates a proof of concept.

\section{DISCUSSION}

A prototype generic biosecurity risk assessment model for import pathways based on a Bayesian Network (BN) tool was created and described. The tool takes into account the likelihood of the infestation rate of a biosecurity risk organism at pathway sources, the movement of commodity units, effectiveness of mitigation measures to limit the movement of organisms and eradication of established populations, pest establishment and spread rates, and costs associated with establishment and spread events. The tool is designed to be generic, so that it can be applied to a range of plant-based risk organisms and entry pathways. Often this information is collected as part of a standard pest risk assessment and as part of determining appropriate pest management processes for quarantine pests (Anon 2006, 2012).

The BN tool can be used: to understand the contribution of different pathways to the likelihood of entry of pests and to evaluate their contribution to the likelihood of establishment and spread; to predict areas of likelihoods of establishment and spread, which can in turn be used to inform cost-effective surveillance measures; to trial alternative resource allocation and risk management strategies; to explore 'what-if scenarios; and to identify knowledge gaps and provide sensitivity analysis to guide future research and data collection (Mengersen et al. 2012; Whittle et al. 2012).

The next steps for the generic biosecurity risk assessment model for import pathways are to develop input spreadsheets to drive the tool; investigate an alternative tool/approach that could handle evidence entered in intermediate nodes; generate outputs; and to test the tool on real-world inputs for three case studies (e.g. Queensland fruit fly, brown marmorated stink bug and the wheat fungus Tilletia indica) based on spreadsheet inputs generated from domain experts.

\section{ACKNOWLEDGEMENTS}

Thanks to Nihal De Silva and Alistair Hall for valuable input to an initial $\mathrm{BN}$ model, also, Alistair Hall and David Teulon for valuable comments on the draft manuscript. The research was funded through Plant \& Food Research core funding as part of the Better Border Biosecurity (B3) (www.b3nz.org) research collaboration.

\section{REFERENCES}

Anon 2006. Risk Analysis Procedures. http:// www.mpi.govt.nz/importing/overview/ import-health-standards/risk-analysis/.

Anon 2012. Guidelines on Pest Risk Analysis Decision-support scheme for an Express Pest Risk Analysis. Bulletin OEPP/EPPO 42(3): 457-462.

Jamieson LE, DeSilva HN, Worner SP, Rogers DJ, Hill MG, Walker JTS 2013. A review of methods for assessing and managing market access and biosecurity risks using systems approaches. New Zealand Plant Protection 66: 1-9.

Mengersen K, Quinlan MM, Whittle PJL, Knight JD, Mumford JD, Wan Ismail WN, Tahir H, Holt J, Leach AW, Johnson S, Sivapragasam A, Lum KY, Sue MJ, Othman Y, Jumaiyah L, Tu DM, Anh NT, Pradyabumrung T, Salyapongse C, Marasigan LQ, Palacpac MB, Dulce L, Panganiban GGF, Soriano TL, Carandang E, Hermawan 2012. Beyond compliance: project on an integrated systems approach for pest risk management in South East Asia. Bulletin OEPP/EPPO Bulletin 42(1): 109-116.

Whittle P, Johnson S, Leach A, Holt J, Quinlan M, 
Mengersen K, Mumford J 2012. Developing systems approaches for phytosanitary pest risk management using control point bayesian networks. Fourth Annual Conference of the Australasian Bayesian Network Modelling Society (ABNMS2012), University of Wollongong. http://abnms.org/conferences/ abnms2012/program.php.
Wintle BC, Nicholson A 2014. Exploring risk judgments in a trade dispute using bayesian networks. Risk Analysis 34(6): 1095-1111. 
ANNEX Table 2 Pathway sub-model for the generic biosecurity risk assessment model for imports. Description of the variables and their relationship to one another.

\begin{tabular}{|c|c|c|c|c|}
\hline $\begin{array}{l}\text { Node/Sub- } \\
\text { model }\end{array}$ & Description & Units & Parents & $\begin{array}{l}\text { Relation- } \\
\text { ship }\end{array}$ \\
\hline Month & $\begin{array}{l}\text { Month of the current model run. } \\
\text { Value is entered as an integer } \\
\text { representing the month. }\end{array}$ & $\begin{array}{l}\text { Enumerated } \\
\text { Month } \\
\text { (e.g., Jan=1, } \\
\text { Feb }=2, \ldots \text {...) }\end{array}$ & $\begin{array}{l}\text { Month (Top } \\
\text { Level) }\end{array}$ & NA \\
\hline $\begin{array}{l}\text { Source Pest } \\
\text { Density } \\
\text { (SPD) }\end{array}$ & $\begin{array}{l}\text { Original pest density at source, } \\
\text { i.e. the chance that any import } \\
\text { unit will be infected (before any } \\
\text { border detection and treatment } \\
\text { considerations). }\end{array}$ & $\begin{array}{l}\text { Density of } \\
\text { pests: }[0-1]\end{array}$ & Month & $\begin{array}{l}\text { Switches } \\
\text { between } \\
\text { month } \\
\text { specific } \\
\text { inputs }\end{array}$ \\
\hline $\begin{array}{l}\text { Pre-Border } \\
\text { Pest } \\
\text { Density } \\
\text { (PreBD) }\end{array}$ & $\begin{array}{l}\text { Density of pests leaving export } \\
\text { country, incorporating treatment } \\
\text { measures taken to ensure the unit is } \\
\text { pest-free before departure. }\end{array}$ & $\begin{array}{l}\text { Density of } \\
\text { pests: }[0-1]\end{array}$ & $\begin{array}{l}\text { Source Pest } \\
\text { Density (SPD), } \\
\text { Pre-Border } \\
\text { Treatment } \\
\text { Efficacy } \\
\text { (PreTE) }\end{array}$ & $\begin{array}{l}\text { SPD * }(1- \\
\text { PreTE })\end{array}$ \\
\hline $\begin{array}{l}\text { Post } \\
\text { Border Pest } \\
\text { Density } \\
\text { (PstBD }\end{array}$ & $\begin{array}{l}\text { Density of pests leaving border } \\
\text { control of the import country, } \\
\text { incorporating natural mortality and } \\
\text { treatment measures used along the } \\
\text { pathway to ensure the unit is 'pest- } \\
\text { free' upon arrival. }\end{array}$ & $\begin{array}{l}\text { Density of } \\
\text { pests: }[0-1]\end{array}$ & $\begin{array}{l}\text { Pre-Border } \\
\text { Pest Density, } \\
\text { Post- Border } \\
\text { Treatment } \\
\text { Efficacy } \\
\text { (PstTE), } \\
\text { Natural } \\
\text { Mortality (NM) }\end{array}$ & $\begin{array}{l}\text { PreBD* }(1 \\
- \text { PstTE })^{*} \\
(1-\mathrm{NM})\end{array}$ \\
\hline $\begin{array}{l}\text { (Pre-) } \\
\text { Border } \\
\text { Detection } \\
\text { (BD) } \\
\end{array}$ & $\begin{array}{l}\text { The detection rate of the exporting/ } \\
\text { importing port, that is, the } \\
\text { probability that an infected unit will } \\
\text { be detected. }\end{array}$ & $\begin{array}{l}\text { Probability } \\
\text { of detection: } \\
{[0-1]}\end{array}$ & NA & NA \\
\hline $\begin{array}{l}\text { (Pre-) } \\
\text { Border } \\
\text { Treatment } \\
\text { (BT) }\end{array}$ & $\begin{array}{l}\text { The treatment efficacy of the } \\
\text { exporting/importing port, That } \\
\text { is, the probability that a detected } \\
\text { infected unit will be successfully } \\
\text { killed/eliminated. }\end{array}$ & $\begin{array}{l}\text { Probability } \\
\text { of successful } \\
\text { treatment: } \\
{[0-1]}\end{array}$ & NA & NA \\
\hline $\begin{array}{l}\text { (Pre-) } \\
\text { Border } \\
\text { Treatment } \\
\text { Efficacy } \\
\text { (TE) }\end{array}$ & $\begin{array}{l}\text { Summary of the treatment efficacy } \\
\text { of the exporting/importing port, } \\
\text { that is, the probability that an } \\
\text { infected unit will be successfully } \\
\text { detected and killed/eliminated. }\end{array}$ & $\begin{array}{l}\text { Probability } \\
\text { of infected } \\
\text { unit } \\
\text { removal: } \\
{[0-1]}\end{array}$ & $\begin{array}{l}\text { Pre-Border } \\
\text { Detection, } \\
\text { Pre-Border } \\
\text { Treatment }\end{array}$ & $\mathrm{BD}^{\star} \mathrm{BT}$ \\
\hline $\begin{array}{l}\text { Natural } \\
\text { Mortality } \\
(\mathrm{NM})\end{array}$ & $\begin{array}{l}\text { Natural mortality of the pest during } \\
\text { transport, that is, the probability } \\
\text { that an individual pest/disease will } \\
\text { die in transit. }\end{array}$ & $\begin{array}{l}\text { Probability } \\
\text { of death: } \\
{[0-1]}\end{array}$ & NA & NA \\
\hline
\end{tabular}


ANNEX Table 3 Exposure sub-model in the generic biosecurity risk assessment model for imports. Description of the variables and their relationship to one another.

\begin{tabular}{llll}
\hline $\begin{array}{l}\text { Node/Sub- } \\
\text { Model }\end{array}$ & Description & Pnits & Relationship \\
\end{tabular}

\begin{tabular}{|c|c|c|c|}
\hline Month & $\begin{array}{l}\text { Month of the current } \\
\text { model run. Value is } \\
\text { entered as an integer } \\
\text { representing the month. }\end{array}$ & $\begin{array}{l}\text { Enumerated } \\
\text { Month (e.g., } \\
\text { Jan=1, Feb=2, } \\
\ldots \text {...) }\end{array}$ & $\begin{array}{l}\text { Month (Top } \\
\text { Level) }\end{array}$ \\
\hline
\end{tabular}

\begin{tabular}{|c|c|c|c|c|}
\hline $\begin{array}{l}\text { Distribution } \\
\text { Location (Dist) }\end{array}$ & $\begin{array}{l}\text { Percentage of units } \\
\text { arriving along pathway } \\
\text { that will be distributed } \\
\text { to location. }\end{array}$ & $\begin{array}{l}\text { Percentage of } \\
\text { units: }[0-1]\end{array}$ & NA & NA \\
\hline Units & $\begin{array}{l}\text { Total number of units } \\
\text { arriving on pathway. }\end{array}$ & $\begin{array}{l}\text { Number of } \\
\text { units: }[0-\text { inf }]\end{array}$ & Month & $\begin{array}{l}\text { Switches } \\
\text { between month } \\
\text { specific inputs }\end{array}$ \\
\hline Pests Per Unit & $\begin{array}{l}\text { Number of pests found } \\
\text { on an infected unit } \\
\text { coming from a pathway. }\end{array}$ & $\begin{array}{l}\text { Number of } \\
\text { pests: }[0-\text { inf }]\end{array}$ & NA & NA \\
\hline $\begin{array}{l}\text { Post Border Pest } \\
\text { Density (PstBD) }\end{array}$ & $\begin{array}{l}\text { Density of pests leaving } \\
\text { border control at import } \\
\text { country. }\end{array}$ & $\begin{array}{l}\text { Density of } \\
\text { pests: }[0-1]\end{array}$ & $\begin{array}{l}\text { Post Border } \\
\text { Pest Density } \\
\text { (Pathway) }\end{array}$ & NA \\
\hline $\begin{array}{l}\text { Pests Entering } \\
\text { (Pests) }\end{array}$ & $\begin{array}{l}\text { Number of pests } \\
\text { entering the location } \\
\text { from the pathway. }\end{array}$ & $\begin{array}{l}\text { Number of } \\
\text { pests: }[0-\text { inf }]\end{array}$ & $\begin{array}{l}\text { Distribution } \\
\text { location, Units, } \\
\text { Post Border } \\
\text { Pest Density, } \\
\text { Pests Per Unit }\end{array}$ & $\begin{array}{l}\text { Binomial } \\
\text { (Units* Dist, } \\
\text { PstBD)* } \\
\text { PestsPerUnit }\end{array}$ \\
\hline $\begin{array}{l}\text { Exposure Rate } \\
\text { (ER) }\end{array}$ & $\begin{array}{l}\text { Chance of arriving } \\
\text { pests being exposed to } \\
\text { environment. }\end{array}$ & $\begin{array}{l}\text { Probability of } \\
\text { exposure: }[0-1]\end{array}$ & NA & NA \\
\hline Exposure Pests & $\begin{array}{l}\text { Number of pests, from } \\
\text { pathway, exposed at } \\
\text { location. }\end{array}$ & $\begin{array}{l}\text { Number of } \\
\text { pests }[0-\text { inf }]\end{array}$ & $\begin{array}{l}\text { Pests entering, } \\
\text { Exposure Rate }\end{array}$ & $\begin{array}{l}\text { Binomial } \\
\text { (Pests, ER) }\end{array}$ \\
\hline
\end{tabular}


ANNEX Table 4 Location sub-model for the generic biosecurity risk assessment model for imports. Description of the variables and their relationship to one another.

\begin{tabular}{|c|c|c|c|c|}
\hline $\begin{array}{l}\text { Node/Sub- } \\
\text { model }\end{array}$ & Description & Units & Parents & Relationship \\
\hline Month & $\begin{array}{l}\text { Month of the current } \\
\text { model run. Value is } \\
\text { entered as an integer } \\
\text { representing the month. }\end{array}$ & $\begin{array}{l}\text { Enumerated } \\
\text { Month (e.g., } \\
\text { Jan=1, Feb=2, } \\
\ldots \text {..) }\end{array}$ & Month (Top Level) & NA \\
\hline $\begin{array}{l}\text { Pathway } \\
1,2, \ldots \\
\text { Exposure } \\
\text { Pests }\end{array}$ & $\begin{array}{l}\text { Each connected } \\
\text { pathway's contribution } \\
\text { to the location exposure } \\
\text { pests (discussed below). }\end{array}$ & NA & NA & NA \\
\hline $\begin{array}{l}\text { Exposure } \\
\text { Pests (EP) }\end{array}$ & $\begin{array}{l}\text { Aggregation of exposure } \\
\text { pests arriving from all } \\
\text { pathways. }\end{array}$ & $\begin{array}{l}\text { Number of pests } \\
{[0-\text { inf }]}\end{array}$ & $\begin{array}{l}\text { Pathway } 1,2, \ldots \\
\text { Exposure Pests }\end{array}$ & $\begin{array}{l}\text { SUM(exp } \\
\text { pests1, exp } \\
\text { pests } 2, \ldots)\end{array}$ \\
\hline $\begin{array}{l}\text { Establish- } \\
\text { ment Rate } \\
\text { (ER) }\end{array}$ & $\begin{array}{l}\text { Probability that an } \\
\text { individual pest will } \\
\text { trigger an establishment } \\
\text { at the location. }\end{array}$ & $\begin{array}{l}\text { Probability of } \\
\text { establish- } \\
\text { ment: }[0-1]\end{array}$ & Month & $\begin{array}{l}\text { Switches } \\
\text { between } \\
\text { month specific } \\
\text { inputs }\end{array}$ \\
\hline $\begin{array}{l}\text { Establish- } \\
\text { ment } \\
\text { (Estab) }\end{array}$ & $\begin{array}{l}\text { Will there be an } \\
\text { establishment at the } \\
\text { location? (Boolean: } \\
\text { False=0, True=1). }\end{array}$ & $\begin{array}{l}\text { Enumerated } \\
\text { Boolean } \\
\text { (False }=0 \text {, } \\
\text { True }=1)\end{array}$ & $\begin{array}{l}\text { Exposure Pests, } \\
\text { Establishment Rate }\end{array}$ & $\begin{array}{l}\text { Bernoulli }(1- \\
\left.(1-\mathrm{ER})^{\wedge} \mathrm{EP}\right)\end{array}$ \\
\hline Spread & $\begin{array}{l}\text { Will there be a spread } \\
\text { event at the location? } \\
\text { (Boolean: False }=0 \text {, } \\
\text { True=1). }\end{array}$ & $\begin{array}{l}\text { Enumerated } \\
\text { Boolean } \\
(\text { False }=0, \\
\text { True }=1)\end{array}$ & $\begin{array}{l}\text { Establishment, } \\
\text { Eradication } \\
\text { Efficacy (EE), } \\
\text { Spread Rate (SR) }\end{array}$ & $\begin{array}{l}\text { IF Estab = 1 } \\
\& \& \text { Bernoulli } \\
(\mathrm{EE})=0 \\
\text { THEN } \\
\text { Bernoulii (SR) } \\
\text { ELSE 0 }\end{array}$ \\
\hline $\begin{array}{l}\text { Eradication } \\
\text { Detection } \\
\text { (ED) }\end{array}$ & $\begin{array}{l}\text { Chance that an } \\
\text { establishment will be } \\
\text { detected. }\end{array}$ & $\begin{array}{l}\text { Probability of } \\
\text { detection: }[0-1]\end{array}$ & NA & NA \\
\hline $\begin{array}{l}\text { Eradication } \\
\text { Control } \\
(\mathrm{EC})\end{array}$ & $\begin{array}{l}\text { Chance that a detected } \\
\text { establishment will be } \\
\text { eradicated. }\end{array}$ & $\begin{array}{l}\text { Probability of } \\
\text { eradication: } \\
{[0-1]}\end{array}$ & NA & NA \\
\hline $\begin{array}{l}\text { Eradication } \\
\text { Efficacy } \\
(\mathrm{EE})\end{array}$ & $\begin{array}{l}\text { Efficacy of eradication } \\
\text { efforts, that is, the } \\
\text { chance that a detected } \\
\text { establishment will be } \\
\text { successfully killed/ } \\
\text { eliminated. }\end{array}$ & $\begin{array}{l}\text { Probability } \\
\text { of successful } \\
\text { eradication: } \\
{[0-1]}\end{array}$ & $\begin{array}{l}\text { Eradication } \\
\text { Detection, } \\
\text { Eradication } \\
\text { Control }\end{array}$ & $\mathrm{ED}^{\star} \mathrm{EC}$ \\
\hline $\begin{array}{l}\text { Spread Rate } \\
(\mathrm{SR})\end{array}$ & $\begin{array}{l}\text { Chance that an } \\
\text { established population } \\
\text { will spread. }\end{array}$ & $\begin{array}{l}\text { Probability of } \\
\text { spread: }[0-1]\end{array}$ & NA & NA \\
\hline
\end{tabular}


ANNEX Table 5 Consequences sub-model in the generic biosecurity risk assessment model for imports. Description of the variables and their relationship to one another.

\begin{tabular}{|c|c|c|c|c|}
\hline $\begin{array}{l}\text { Node/Sub- } \\
\text { model }\end{array}$ & Description & Units & Parents & Relationship \\
\hline Establishment & $\begin{array}{l}\text { Do the pests } \\
\text { establish at the } \\
\text { infection point? }\end{array}$ & $\begin{array}{l}\text { Enumerated } \\
\text { Boolean } \\
(\text { False }=0 \\
\text { True }=1)\end{array}$ & \multirow{2}{*}{\multicolumn{2}{|c|}{ Values copied from Location model }} \\
\hline Spread & $\begin{array}{l}\text { Do the pests } \\
\text { spread at the } \\
\text { infection point? }\end{array}$ & $\begin{array}{l}\text { Enumerated } \\
\text { Boolean } \\
(\text { False }=0 \\
\text { True }=1)\end{array}$ & & \\
\hline $\begin{array}{l}\text { Economic } \\
\text { Consequence }\end{array}$ & $\begin{array}{l}\text { Expected } \\
\text { economic costs } \\
\text { associated } \\
\text { with pest } \\
\text { establishment } \\
\text { and spread. }\end{array}$ & $\begin{array}{l}\text { Economic } \\
\text { units }\end{array}$ & $\begin{array}{l}\text { Establishment (E), } \\
\text { Spread (S), Economic } \\
\text { Est. Cost* (EEC), } \\
\text { Economic Spread Cost* } \\
\text { (ESC) }\end{array}$ & $\begin{array}{l}\text { Deterministic } \\
\text { function: } \\
\text { (If E then EEC, else } \\
0)+(\text { If S then ESC, } \\
\text { else 0) }\end{array}$ \\
\hline $\begin{array}{l}\text { Environmental } \\
\text { Consequence }\end{array}$ & $\begin{array}{l}\text { Expected } \\
\text { environmental } \\
\text { costs associated } \\
\text { with pest } \\
\text { establishment } \\
\text { and spread. }\end{array}$ & $\begin{array}{l}\text { Environ- } \\
\text { mental units }\end{array}$ & $\begin{array}{l}\text { Establishment } \\
\text { (E), Spread (S), } \\
\text { Environmental } \\
\text { Est. Cost* (EEC), } \\
\text { Environmental Spread } \\
\text { Cost* }^{*} \text { ESC) }\end{array}$ & $\begin{array}{l}\text { Deterministic } \\
\text { function: } \\
\text { (If E then EEC, else } \\
0)+(\text { If S then ESC, } \\
\text { else 0) }\end{array}$ \\
\hline $\begin{array}{l}\text { Human Health } \\
\text { Consequence }\end{array}$ & $\begin{array}{l}\text { Expected } \\
\text { human health } \\
\text { costs associated } \\
\text { with pest } \\
\text { establishment } \\
\text { and spread. }\end{array}$ & $\begin{array}{l}\text { Human } \\
\text { Health units }\end{array}$ & $\begin{array}{l}\text { Establishment (E), } \\
\text { Spread (S), Human } \\
\text { Health Est. Cost* } \\
\text { (HEC), Human Health } \\
\text { Spread Cost* (HSC) }\end{array}$ & $\begin{array}{l}\text { Deterministic } \\
\text { function: } \\
\text { (If E then HEC, else } \\
0)+(\text { If S then HSC, } \\
\text { else } 0 \text { ) }\end{array}$ \\
\hline $\begin{array}{l}\text { Social/Cultural } \\
\text { Consequence }\end{array}$ & $\begin{array}{l}\text { Expected } \\
\text { social/cultural } \\
\text { costs associated } \\
\text { with pest } \\
\text { establishment } \\
\text { and spread. }\end{array}$ & $\begin{array}{l}\text { Social/ } \\
\text { Cultural units }\end{array}$ & $\begin{array}{l}\text { Establishment (E), } \\
\text { Spread (S), Social/ } \\
\text { Cultural Est. Cost } \\
\text { (SCEC), Social/Cultural } \\
\text { Spread Cost }^{*} \text { (SCSC) }\end{array}$ & $\begin{array}{l}\text { Deterministic } \\
\text { function: } \\
\text { (If E then SCEC, else } \\
0)+(\text { If S then SCSC, } \\
\text { else 0) }\end{array}$ \\
\hline
\end{tabular}

${ }^{\star}$ Pest/Infection Point specific input 


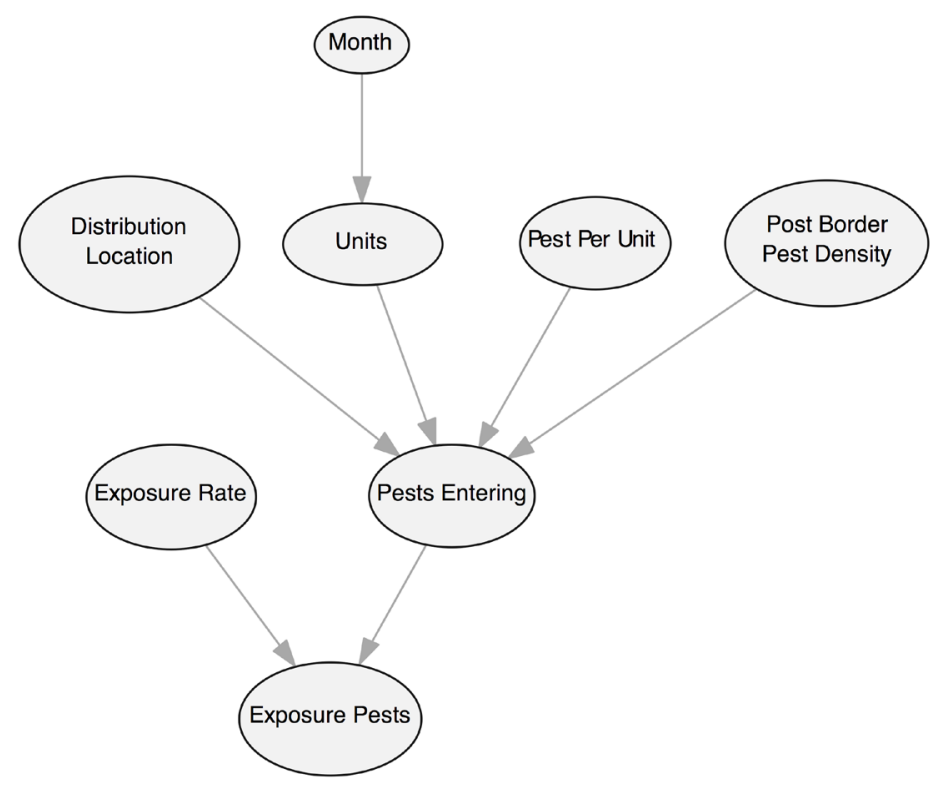

ANNEX Figure 4 The Exposure sub-model for the generic biosecurity risk assessment model for imports with component nodes/sub-models.

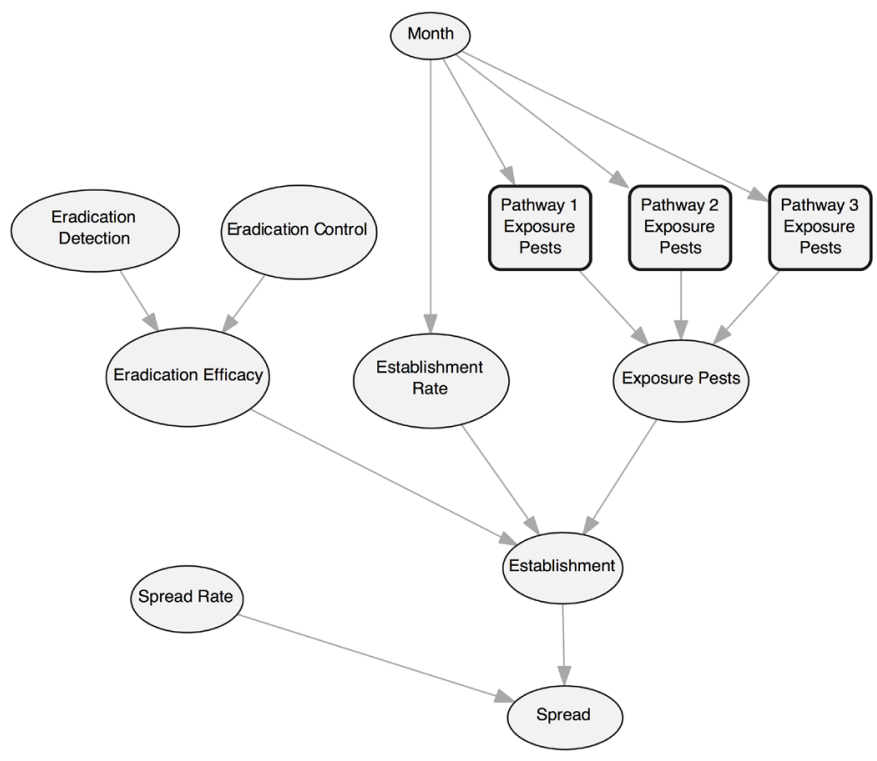

ANNEX Figure 5 The Location sub-model for the generic biosecurity risk assessment model for imports with component nodes/sub-models. 


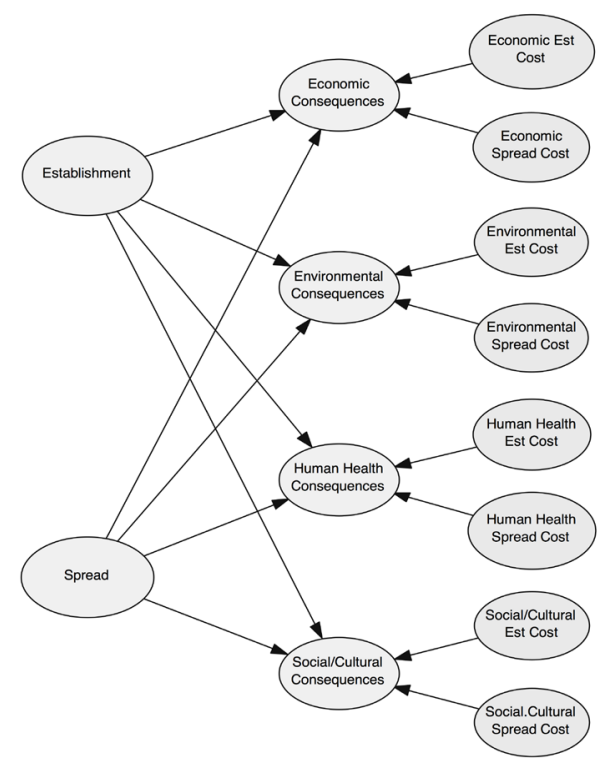

ANNEX Figure 6 The Consequences sub-model for the generic biosecurity risk assessment model for imports with component nodes/sub-models. Est = Establishment. 